OAK RIDGE

NATIONAL LABORATORY

MANAGED BY UT-BATTELLE

FOR THE DEPARTMENT OF ENERGY
ORNL/NTRC-001

Rev. 0

\title{
DESIGN AND CERTIFICATION OF TARGETS FOR DROP TESTS AT THE NTRC PACKAGING RESEARCH FACILITY
}

May 2003

Revision 0
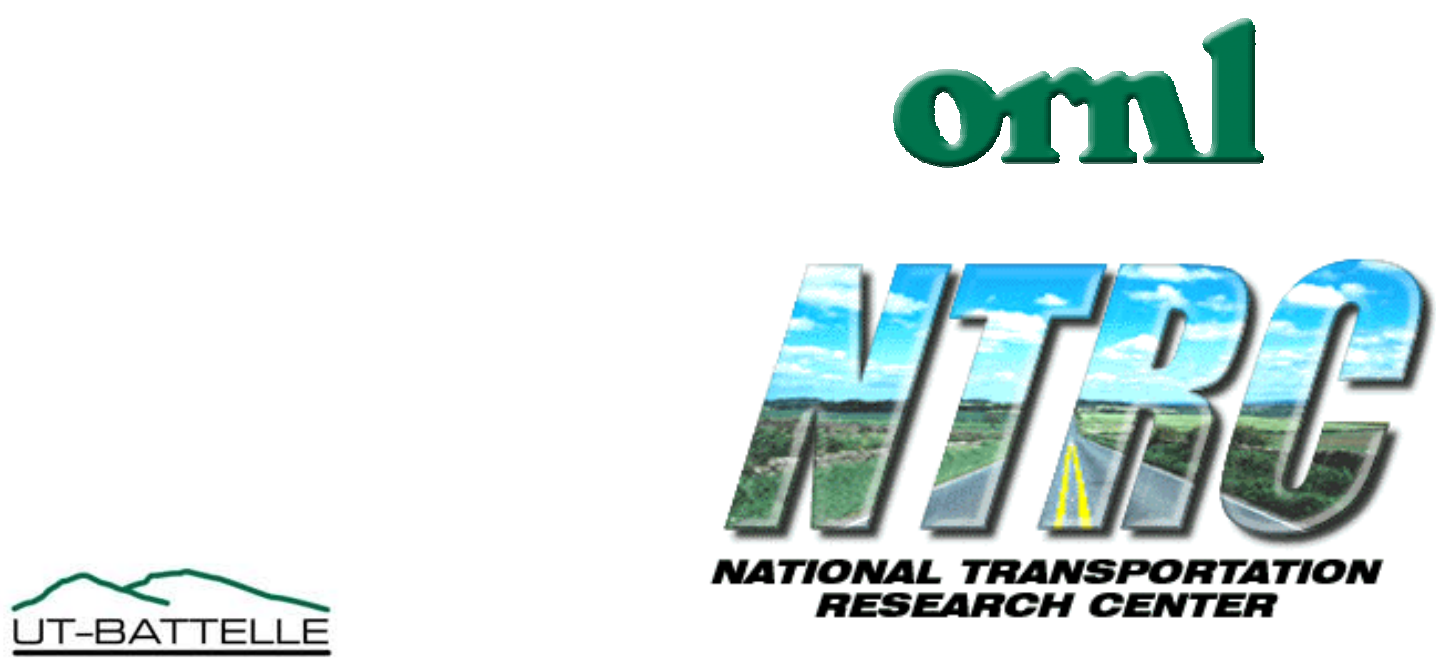


\section{DOCUMENT AVAILABILITY}

Reports produced after January 1, 1996, are generally available free via the U.S. Department of Energy (DOE) Information Bridge.

Web site http://www.osti.gov/bridge

Reports produced before January 1,1996, may be purchased by members of the public from the following source:

National Technical Information Service

5285 Port Royal Road

Springfield, VA 22161

Telephone 703-605-6000 (1-800-553-6847)

TDD 703-487-4639

Fax 703-605-6900

E-mail info@ntis.fedworld.gov

Web site http://www.ntis.gov/support/ordernowabout.htm

Reports are available to DOE employees, DOE contractors, Energy Technology Data Exchange (ETDE) representatives, and International Nuclear Information System (INIS) representatives from the following source.

Office of Scientific and Technical Information

P.O. Box 62

Oak Ridge, TN 37831

Telephone 865-576-8401

Fax 865-576-5728

E-mail reports@adonis.osti.gov

Web site http://www.osti.gov/contact.html

This report was prepared as an account of work sponsored by an agency of the United States Government. Neither the United States Government nor any agency thereof, nor any of their employees, makes any warranty, express or implied, or assumes any legal liability or responsibility for the accuracy, completeness, or usefulness of any information, apparatus, product, or process disclosed, or represents that its use would not infringe privately owned rights. Reference herein to any specific commercial product, process, or service by trade name, trademark, manufacturer, or otherwise, does not necessarily constitute or imply its endorsement, recommendation, or favoring by the United States Government or any agency thereof. The views and opinions of authors expressed herein do not necessarily state or reflect those of the United States Government or any agency thereof. 


\section{DESIGN AND CERTIFICATION OF TARGETS FOR DROP TESTS AT THE NTRC PACKAGING RESEARCH FACILITY}

Scott B. Ludwig

Date Published: May 2003

Prepared by the OAK RIDGE NATIONAL LABORATORY

Oak Ridge, Tennessee 37831-6285 managed by

UT-BATTELLE, LLC for the

U.S. DEPARTMENT OF ENERGY under contract DE-AC05-00OR22725 


\section{Revision History}

\begin{tabular}{|c|c|l|}
\hline Revision & Date & Description \\
\hline 0 & $5 / 30 / 2003$ & Initial version. \\
\hline & & \\
\hline & & \\
\hline & & \\
\hline & & \\
\hline & & \\
\hline & & \\
\hline
\end{tabular}




\section{CONTENTS}

Page

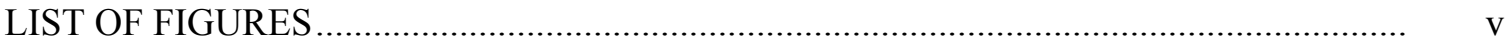

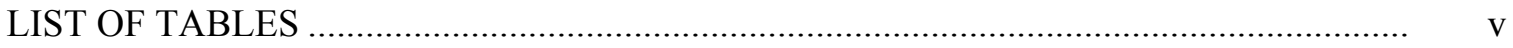

LIST OF ABBREVIATED TERMS …........................................................................ vii

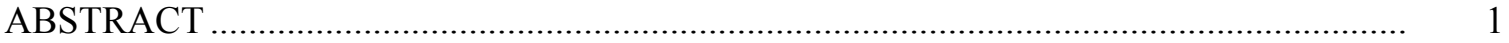

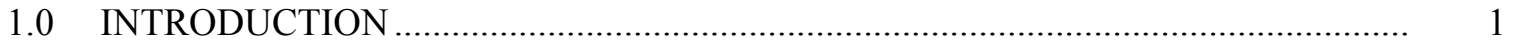

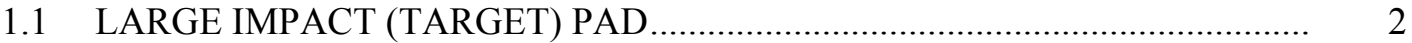

1.2 SMALL IMPACT (TARGET) PAD …........................................................... 2

2.0 DESIGN AND CONSTRUCTION OF NTRC IMPACT PADS ……......................... 5

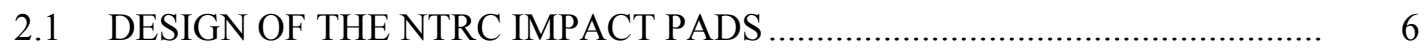

2.2 CONSTRUCTION OF THE NTRC IMPACT PADS ........................................ 10

3.0 CERTIFICATION OF IMPACT TARGETS AS “ESSENTIALLY UNYIELDING”.. 15 3.1 EVALUATION OF THE TOTAL TARGET MASS OF NTRC IMPACT PADS FOR TYPE B TESTS …….............................................................. 15

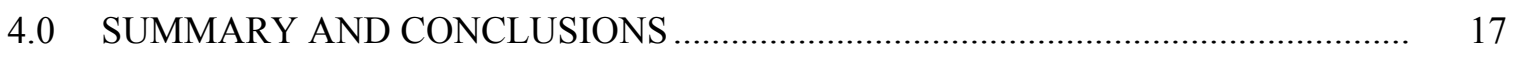

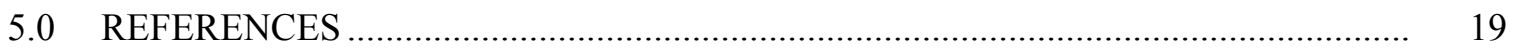


This page intentionally left blank. 


\section{LIST OF FIGURES}

$\begin{array}{lll}\text { Figure } & \text { Page }\end{array}$

1 View of the National Transportation Research Center (NTRC), southwest corner........ 2

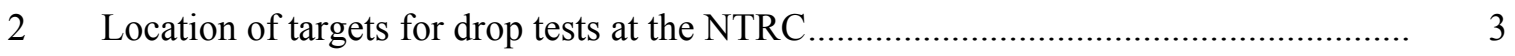

3 General dimensional representation of NTRC impact (target) pads............................. 5

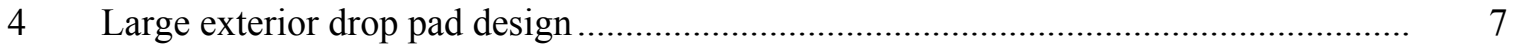

$5 \quad$ Close-up view of large exterior drop pad layout …..................................................... 8

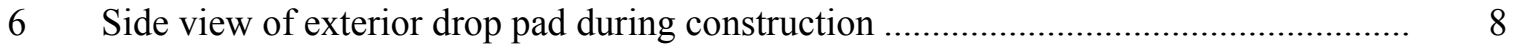

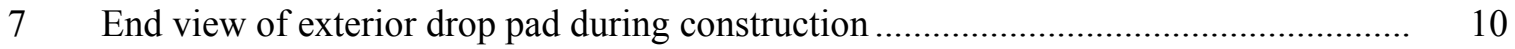

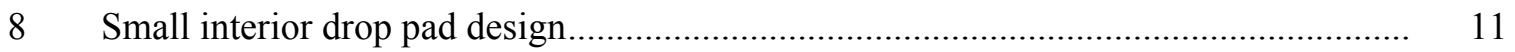

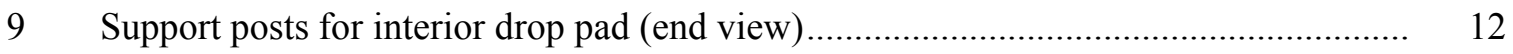

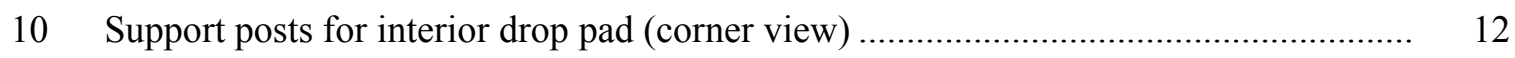

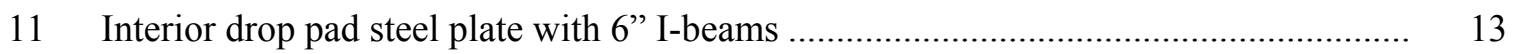

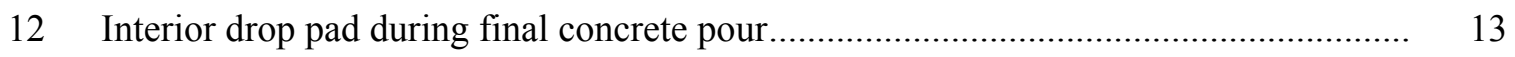

13 Large exterior impact pad at the NTRC Packaging Research Facility ........................ 16

14 Small interior impact pad at the NTRC Packaging Research Facility........................... 16

\section{LIST OF TABLES}

Table

Page

1 Design versus as-built dimensions of NTRC impact pads 
This page intentionally left blank. 


\section{LIST OF ABBREVIATED TERMS}

HAC Hypothetical Accident Conditions

IAEA International Atomic Energy Agency

NCT Normal Conditions of Transport

NRC Nuclear Regulatory Commission

NSTD Nuclear Science and Technology Division

NTRC National Transportation Research Center

ORNL Oak Ridge National Laboratory

PRF Packaging Research Facility

TTG Transportation Technologies Group 
This page intentionally left blank. 


\title{
DESIGN AND CERTIFICATION OF TARGETS FOR DROP TESTS AT THE NTRC PACKAGING RESEARCH FACILITY
}

\begin{abstract}
This report provides documentation of the design and certification of drop pad (targets) at the National Transportation Research Center (NTRC) Packaging Research Facility(PRF). Based on the evaluation performed, it has been demonstrated that the small (interior) drop pad (target) meets the regulatory definition of a flat, essentially unyielding, horizontal surface for packages weighing up to $3,150 \mathrm{lb}(1,432 \mathrm{~kg})$. The large (exterior) drop pad (target) meets the regulatory definition of a flat, essentially unyielding, horizontal surface for packages weighing up to $28,184 \mathrm{lb}(12,811 \mathrm{~kg})$.
\end{abstract}

\subsection{INTRODUCTION}

Strict United States and international regulations govern both the design and use of packages that contain radioactive materials during shipment. Before such package designs are certified as complying with the transportation regulations that would permit their subsequent manufacture and use, the structural integrity of each package design must be demonstrated to show that it will indeed survive severe and improbable accident criteria. Structural integrity of the package design is evaluated to ensure that even under severe accident conditions as defined by the regulations, the package is sufficient robust to:

- not release any of the radioactive contents,

- manifest no significant reduction in the level of radioactive shielding provided by the package, and

- for fissile material packages, remain subcritical in the most reactive configuration consistent with any damage to the package due to the accident.

Since 1960 the Oak Ridge National Laboratory (ORNL) Transportation Technologies Group (TTG) has been involved in conducting drop tests of casks and other containers used for the transport of radioactive materials and spent fuel. Over the years, ORNL has constructed and used impact (target) pads for drop tests on the ORNL site: a small impact pad was constructed in a area close to the ORNL steam plant (Ref. 1), and a much larger pad was built at the Tower Shielding Facility for tests of very large spent fuel casks (Ref. 2).

With the development of the NTRC (shown in Fig. 1), a joint venture between ORNL and the University of Tennessee, came the opportunity to continue and expand the capabilities for conducting packaging research and package testing. Under the auspices of the ORNL Nuclear Science and Technology Division (NSTD), the TTG operates the PRF at the NTRC. During development of the NTRC, the TTG designed two new impact (target) pads for the NTRC, which were then installed as part of the overall construction of the NTRC in 1999-2000. The location of these impact pads at the NTRC is shown in Fig. 2. The small impact pad is located within the PRF, while the large impact pad is located outside the NTRC in an area adjacent to the PRF.

This document provides a description of the design and construction of these new impact (target) pads and provides an evaluation of these targets as certification that they meet the regulatory definition of a "flat, essentially unyielding, horizontal surface" as specified in NRC's regulations governing the packaging and transportation of radioactive material (Ref. 3, $10 \mathrm{CFR}$ Part 71). 


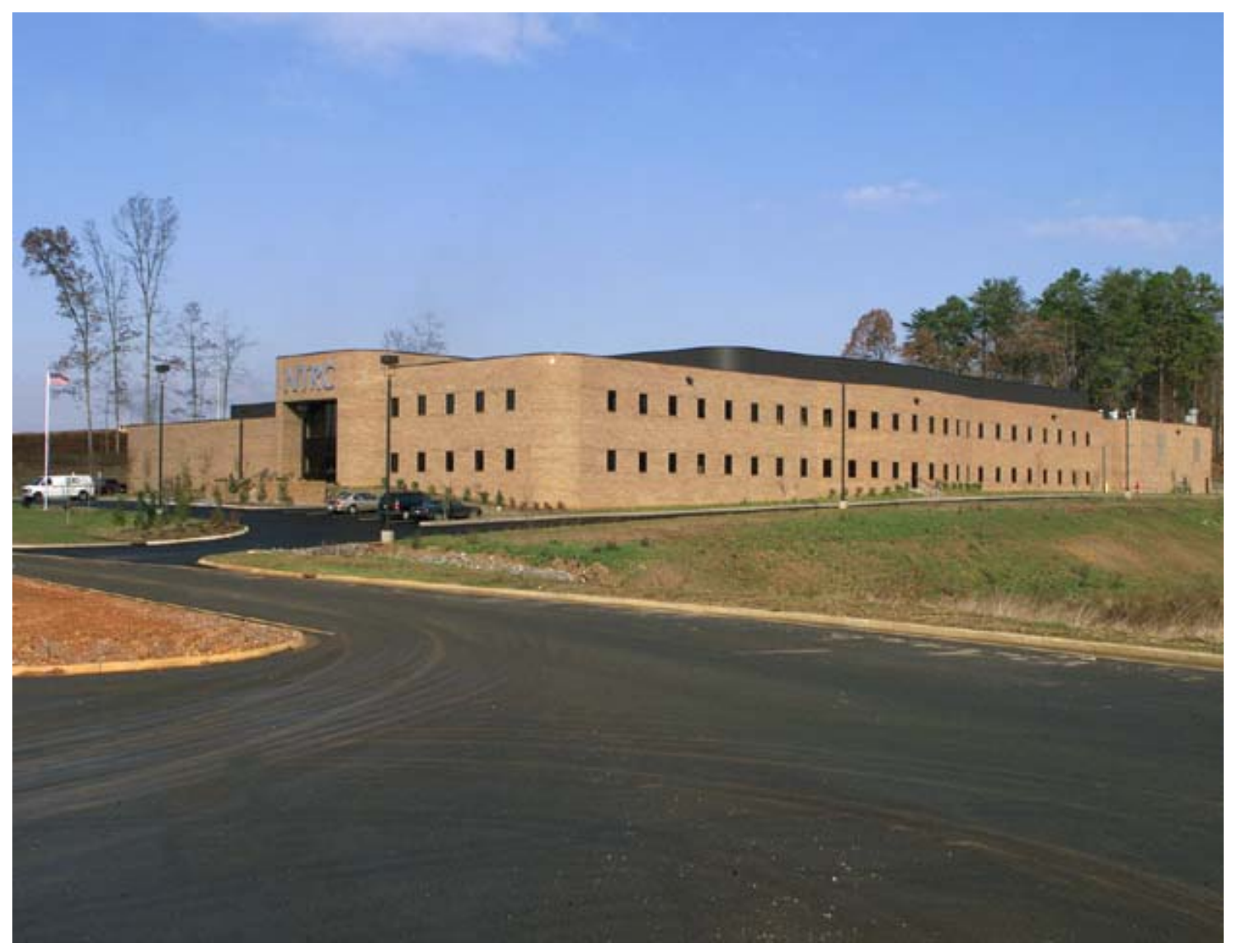

Fig. 1. View of the National Transportation Research Center (NTRC), southwest corner.

\subsection{LARGE IMPACT (TARGET) PAD}

The Large Impact (Target) Pad is located in the parking lot on the north side of the NTRC, adjacent to the PRF. This pad was designed to provide a "flat, essentially unyielding, horizontal surface" for drops of relatively large packages weighing up to approximately 20,000 pounds $(9,072 \mathrm{~kg})$ that would be lifted and released from large mobile cranes that would be brought to the NTRC for that purpose. This impact pad will serve as the primary pad for $9 \mathrm{~m}$ (30-foot) free drops and crushes required to demonstrate compliance of Type B radioactive material package designs when subjected to the Hypothetical Accident Conditions (HAC) tests as described in the NRC regulations (Ref. 3, Sec. 71.73), as well as for demonstrating compliance of very large Type A package designs when subjected to the Normal Conditions of Transport (NCT) tests as described in the NRC regulations (Ref. 3, Sec. 71.71).

\subsection{SMALL IMPACT (TARGET) PAD}

The Small Impact (Target) Pad is located within the PRF (Room L110) at the NTRC. This pad was designed to provide a "flat, essentially unyielding, horizontal surface" for drops of relatively small packages weighing up to approximately 3,000 pounds $(1,364 \mathrm{~kg})$ that would be lifted and released from either the 5-Ton DeShazo Bridge Crane or the Lansmont Precision Drop Tester (Model PDT-56E). This impact pad would serve as the primary pad for free drops required to demonstrate compliance of smaller packages (Type A or Type B radioactive material package designs), as well as other small packages when subjected to NCT tests (Ref. 3, Sec. 71.71). 


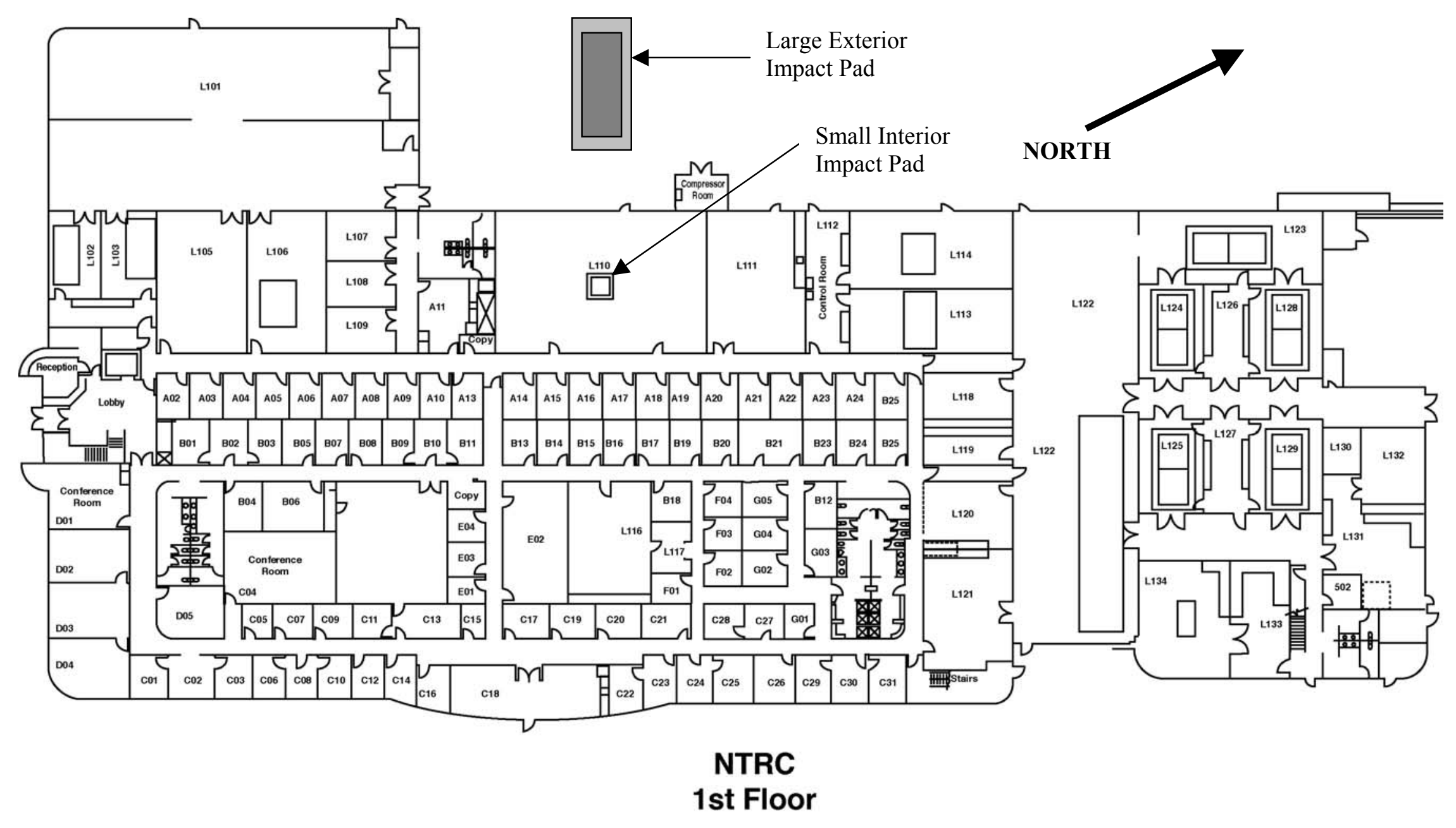

Fig. 2. Location of targets for drop tests at the NTRC. 
This page intentionally left blank. 


\subsection{DESIGN AND CONSTRUCTION OF NTRC IMPACT PADS}

The Large Impact (Target) Pad and the Small Impact (Target) Pad at the NTRC are the latest additions to capabilities at the Oak Ridge National Laboratory for conducting drop tests of radioactive material packages to demonstrate compliance with package approval standards in 10 CFR Part 71. Each of the two impact pads have some common characteristics that serve as "an essentially unyielding surface" intended to cause damage to the package which would be equivalent to, or greater than, that anticipated for impacts onto surfaces or structures which might occur during transport. Each pad is composed of a thick, reinforced concrete slab into which a steel plate is embedded to form the top surface to provide an overall large reaction mass, as well as a stiff surface to cause the maximum damage to the package. Figure 3 provides a simple dimensional representation of each of the impact pads.

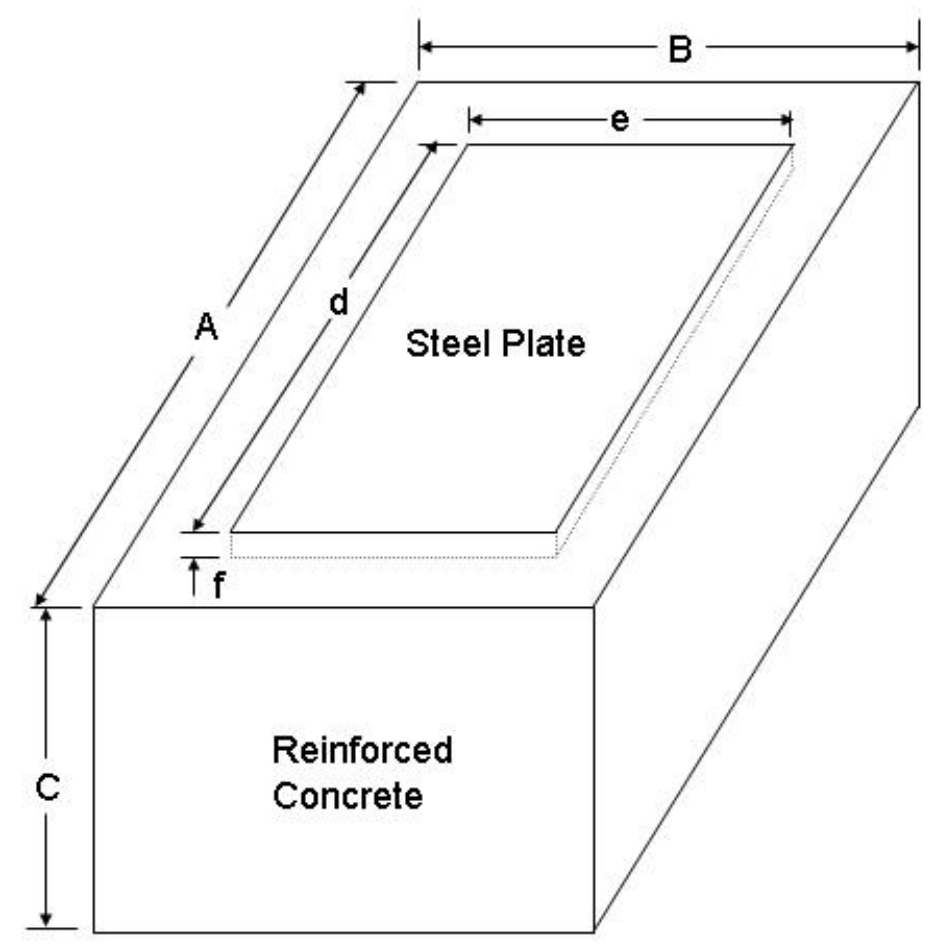

Fig. 3. General dimensional representation of NTRC impact (target) pads.

Table 1 provides a summary of general dimensions for the Large Exterior and Small Interior Impact Pads, showing the "design" versus the "as-built" dimensions. The design dimensions were submitted by ORNL as general dimensional guidance (along with descriptive information about structural reinforcements [rebar] within the concrete and recommendations about anchoring and embedding the steel plate within the upper surface of the concrete) to the NTRC architect (Michael Brady Inc., Knoxville, TN). The NTRC architect then developed architectural drawings (and construction guidance) for the impact pads, which were reviewed (and concurred) by ORNL prior to construction. 
Table 1. Design versus as-built dimensions of NTRC impact pads

\begin{tabular}{|l|c|c|c|c|}
\hline & \multicolumn{2}{|c|}{ Large Exterior Impact Pad } & \multicolumn{2}{c|}{ Small Interior Impact Pad } \\
\hline & Design, in. & As-built, in. & Design, in. & As-built, in. \\
\hline A - length of concrete & $288^{\prime \prime}$ & $300^{\prime \prime}$ & $84 "$ & $99.5^{\prime \prime}$ \\
\hline B - width of concrete & $144^{\prime \prime}$ & $159^{\prime \prime}$ & $84 "$ & $72.5^{\prime \prime}$ \\
\hline C - depth of concrete & $66^{\prime \prime}$ & $66^{\prime \prime}(\mathrm{min})$ & $42^{\prime \prime}$ & $50^{\prime \prime}(\mathrm{min})$ \\
\hline D - length of steel plate & $240^{\prime \prime}$ & $242^{\prime \prime}$ & $60^{\prime \prime}$ & $75.5^{\prime \prime}$ \\
\hline E - width of steel plate & $96^{\prime \prime}$ & $100.5^{\prime \prime}$ & $60^{\prime \prime}$ & $48.25^{\prime \prime}$ \\
\hline F - thickness of steel plate & $4 "$ & $4 "$ & $6 "$ & $2 "$ \\
\hline
\end{tabular}

For the Large Exterior Impact Pad, the "as-built" dimensions ended up being slightly larger than the "design" dimensions. For the Small Interior Impact Pad, the "as built" design was changed due to the unavailability of the 6"-thick steel plate intended for that pad. Instead, a 2"-thick steel plate was substituted (more than sufficient), and changed the actual dimensions of the pad from $60 "$ x $60 "$ to roughly $48 " \times 72 "$. This substitution also enabled this impact pad to serve as the mounting base for the Lansmont PDT-56E Precision Drop Tester.

\subsection{DESIGN OF THE NTRC IMPACT PADS}

Based on interactions between TTG personnel and the NTRC architectural firm, the final design of the NTRC impact pads was completed in June 1999. The design is shown on Sheet No. S14 of the official NTRC blueprints. Figures 4, 5, and 6 were extracted from an image of Sheet No. S14. Figures 4 and 5 show the design of the large (exterior) drop pad, and Fig. 6 shows the design of the small (interior) drop pad. Figure 5 is a close-up of the side (underground) view of Fig. 4.

In order to serve as a flat, essentially unyielding, horizontal surface as specified in the NRC regulations [Ref. 3, Sects. 71.71 (c)(7); 71.71 (c)(8); 71.73 (c)(1); 71.73 (c)(2); and 71.73 (c)(3)], each impact (target) pad must be both sufficiently massive and rigid (stiff) to ensure that the impact of the test specimen with the target is such that maximum damage is expected. The U.S. regulations, however, are silent with respect to the design and construction of such targets. Noting that current (and future) U.S. regulations for radioactive material packages are based on the IAEA regulations (Refs. 4 and 5), examination of these regulations provide a description that the "Target for drop tests" shall be "a flat, horizontal surface of such a character that any increase in its resistance to displacement or deformation upon impact by the specimen would not significantly increase the damage to the specimen." (Ref. 4, Para. 618 and Ref. 5, Para. 717). The IAEA regulations are supported by Explanatory and Advisory Material that provide additional guidance to enable uniform implementation of the regulations.

As described in IAEA Explanatory Material (i.e., Ref. 6, Safety Series 7):

E-618. The target for drop tests is specified as an essentially unyielding surface. This unyielding surface is intended to cause damage to the package which would be equivalent to or greater than that anticipated for impacts onto actual surfaces or structures which might occur during transport. The specified target also provides a method for assuring that analyses and tests can be compared and accurately repeated if necessary. The unyielding target, even though described in general terms, can be repeatedly constructed to provide a relatively large mass and stiffness with respect to the package being tested. So-called real targets, such 


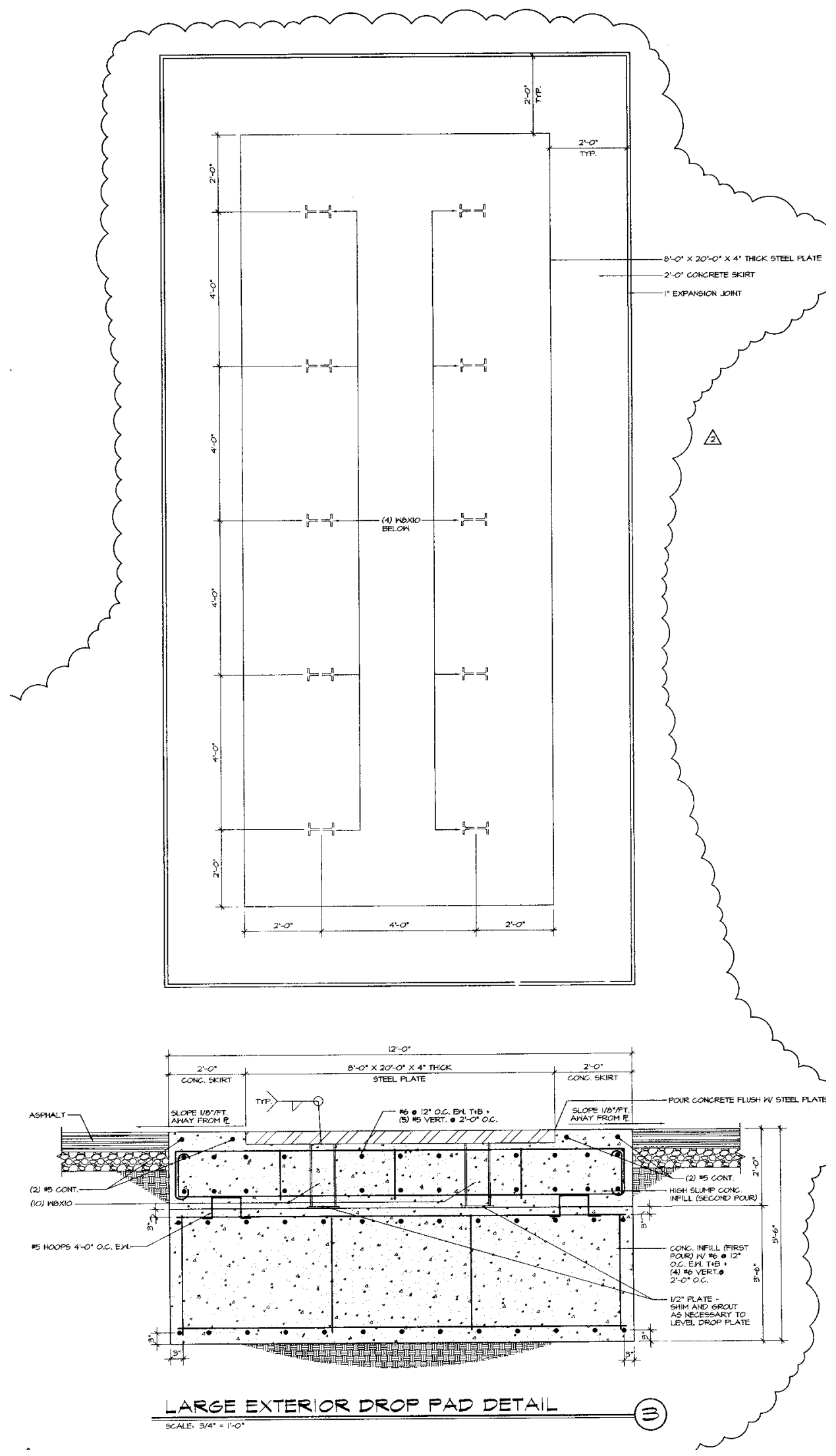

Fig. 4. Large exterior drop pad design. 


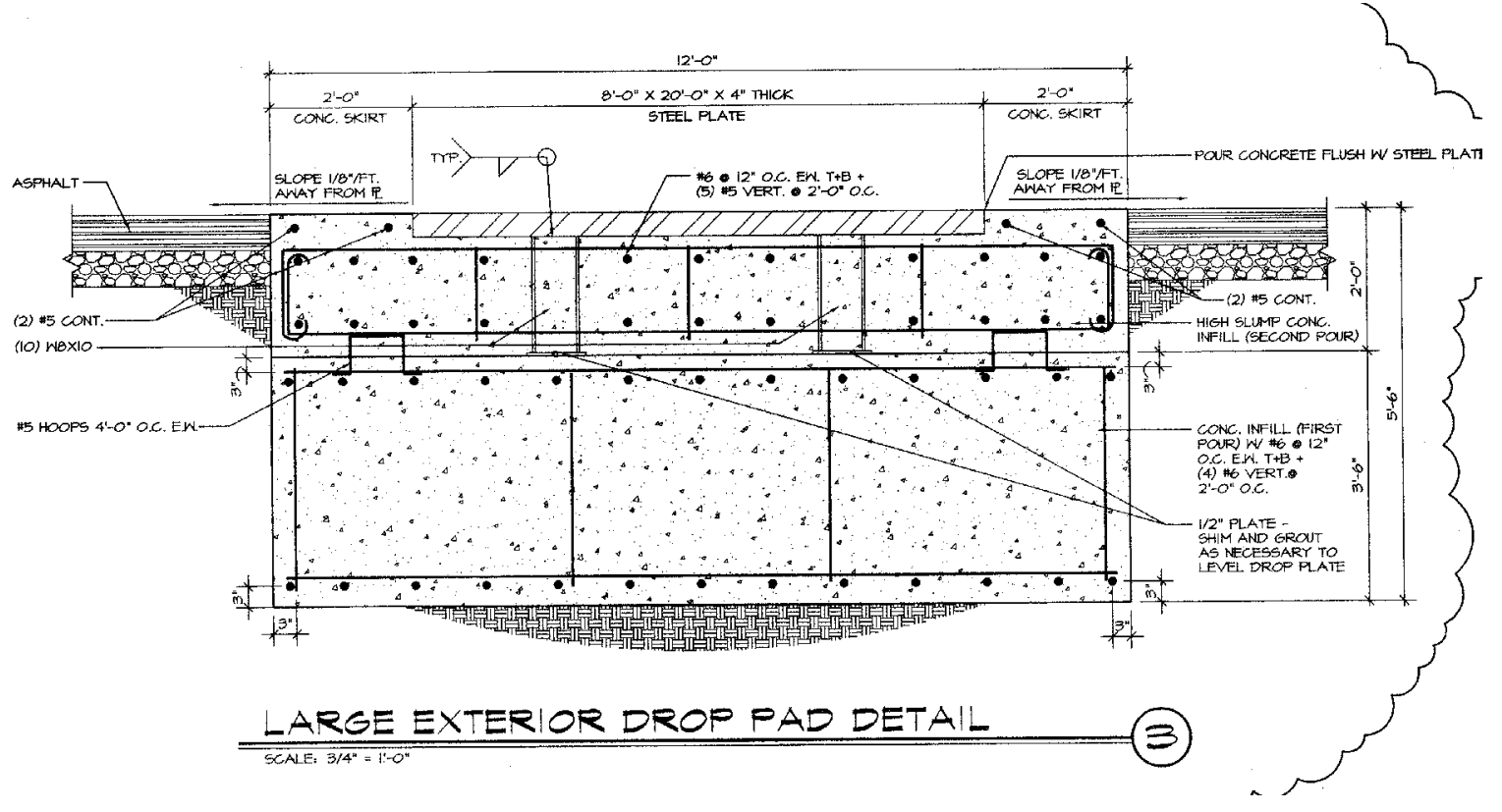

Fig. 5. Close-up view of large exterior drop pad layout.

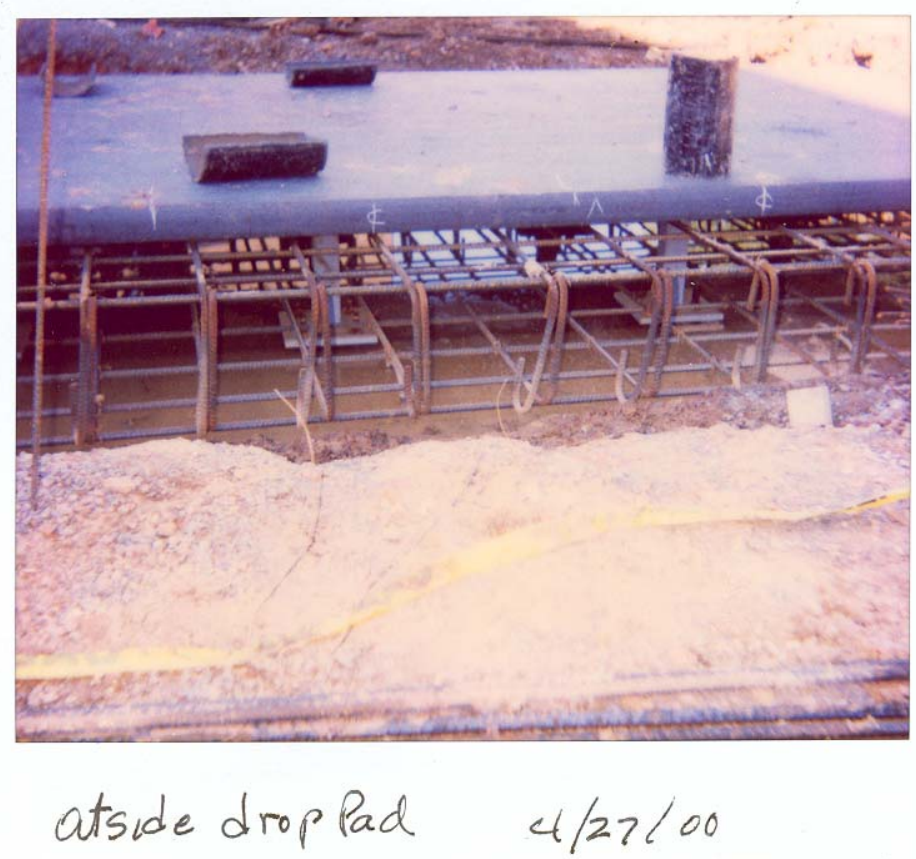

Fig. 6. Side view of exterior drop pad during construction. 
as soil, soft rock and some concrete structures, are less stiff and could cause less damage to a package for a given impact velocity. In addition, it is more difficult to construct yielding surfaces that give reproducible test results, and the shape of the object being dropped can affect the yielding character of the surface. Thus, if yielding targets were used, the uncertainty of the test results would increase and the comparison between calculations and tests would be much more difficult.

And the IAEA Advisory Material (i.e., Ref. 7, Safety Series 37) provides the following description:

A-618. One example of an unyielding target to meet the regulatory requirements is a steel plate as the upper surface of a concrete block. The combined mass of the steel and concrete should be at least 10 times that of the specimen to be dropped on it. The block should be set on firm soil and the steel plate should be at least $4.0 \mathrm{~cm}$ thick and floated on the concrete while it is still wet. The plate should have protruding fixed steel structures on its lower surface to ensure tight contact with the concrete. Since flexure of the target is to be avoided, especially in the vertical direction, it is recommended that the target should be close to cubic in form, with the depth of the target comparable to the width and length. Other targets that have been used are described in Refs. [38, 39].

During the development of the revised IAEA regulations [Ref. 5, TS-R-1 (ST-1)] upon which revisions to the U.S. regulations will be based, the Explanatory and Advisory Material were combined into a single guide of advisory material [Ref. 8, TS-G-1.1 (ST-2)], which remains essentially unchanged from previous versions. For completeness, the guidance is repeated below:

717.1. The target for drop tests is specified as an essentially unyielding surface. This unyielding surface is intended to cause damage to the package which would be equivalent to or greater than that anticipated for impacts onto actual surfaces or structures which might occur during transport. The specified target also provides a method for assuring that analyses and tests can be compared and accurately repeated if necessary. The unyielding target, even though described in general terms, can be repeatedly constructed to provide a relatively large mass and stiffness with respect to the package being tested. So-called real targets, such as soil, soft rock and some concrete structures, are less stiff and could cause less damage to a package for a given impact velocity. In addition, it is more difficult to construct yielding surfaces that give reproducible test results, and the shape of the object being dropped can affect the yielding character of the surface. Thus, if yielding targets were used, the uncertainty of the test results would increase and the comparison between calculations and tests would be much more difficult.

717.2. One example of an unyielding target to meet the regulatory requirements is a $4 \mathrm{~cm}$ thick steel plate floated on to a concrete block mounted on firm soil or bedrock. The combined mass of the steel and concrete should be at least 10 times that of the specimen for the tests in paragraphs 705, 722, 725(a), 727 and 735, and 100 times that of the specimen for the test in paragraph 737, unless a different value can be justified. The steel plate should have protruding fixed steel structures on its lower surface to ensure tight contact with the concrete. The hardness of the steel should be considered when testing packages with hard surfaces. To minimize flexure the concrete should be sufficiently thick, but still allowing for the size of the test sample. Other targets that have been used are 
described in the literature $[7,8]$. Since flexure of the target is to be avoided, especially in the vertical direction, it is recommended that the target should be close to cubic in form with the depth of the target comparable to the width and length.

\subsection{CONSTRUCTION OF THE NTRC IMPACT PADS}

Based on the guidance listed above, the construction of the NTRC impact pads was undertaken. Construction of the NTRC impact pads occurred between February - June 2000.

The large (exterior) impact (target) pad was planned to accommodate drops of large packages weighing up to approximately 20,000 lb. This drop pad (shown in Figs. 4 and 5) has a minimum depth of 66", which was completed in two pours. The lower concrete structure (first pour), with a minimum thickness of 42", contains \#6 rebar positioned at 12" on-center each way at the top and bottom and is connected vertically by four \#6 rebar positioned at $2^{\prime}$ on-center each way and contains \#5 rebar hoops positioned at 4' on-center that protruded above the surface of the first pour. The steel plate (4" thick) is grade A-36 steel purchased from O'Neal Steel and delivered to the NTRC on $4 / 24 / 00$. The steel plate is mounted on ten W8x10 wide-flange I-beams that are approximately 20 "long and has a $1 / 2$ " steel plate welded to the base that serves as a base to rest on the first pour. These beams are positioned at 4 ' intervals. The W8x10 I-beams are then welded to the bottom of the steel plate. Surrounding these beams is the reinforcing rebar for the upper concrete structure (second pour), which contains \#6 rebar positioned at 12" on-center, each at the top and bottom, and is connected vertically by five $\# 5$ rebar at $2^{\prime}$ on-center positions, each way. Figures 6 and 7 show the outside drop pad during construction in April 2000. The second pour of concrete completed this drop pad, bringing the concrete skirt flush with the surface of the steel plate. During this pour, the steel plate was mechanically vibrated to ensure that all air pockets and voids were eliminated. During completion of the NTRC, the area surrounding the impact pad was paved with asphalt.

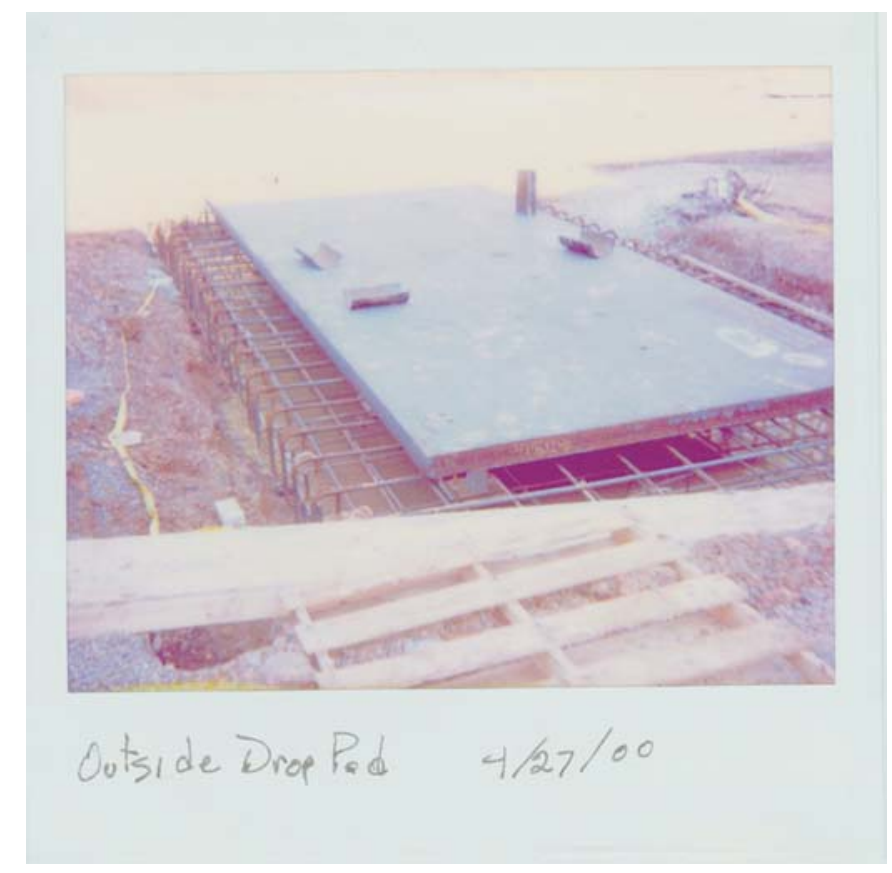

Fig. 7. End view of exterior drop pad during construction. 
The small (interior) impact (target) was planned to accommodate drops of small packages weighing up to approximately 3,000 lb. This drop pad design, shown in Fig. 8, was changed somewhat during construction to allow substitution of a 2" plate for the planned 6" plate. This drop pad has a minimum depth of 50" and was also completed in two pours. First, an 8 "-thick footing was poured, containing \#5 rebar positioned at 12" on-center and each way. The steel plate is supported by a $4 " \mathrm{n} 4$ " steel channel with a $1 / 2$ " plate welded to the bottom to form a base. These steel channels are shown in Figs. 9 and 10. In addition, the steel plate has two 6" I-beams welded to the lower surface, as shown in Fig. 11. These I-beams, welded together with the 4" x 4" steel channels to the lower surface of the steel plate ensure that tight contact between the steel plate and the concrete is maintained. The upper concrete structure (second pour, as shown in Fig. 12) also contains a web of \#6 rebar positioned top and bottom and each way and connected vertically with additional \#6 rebar. The second concrete pour completed this impact pad, bringing the concrete skirt flush with the surface of the steel plate. During this pour, the steel plate was mechanically vibrated to ensure that all air pockets and voids were eliminated. During completion of the NTRC, the PRF lab floor was poured flush with the surface of the impact pad. The impact pad is isolated from the lab floor slab by a 1" expansion joint.

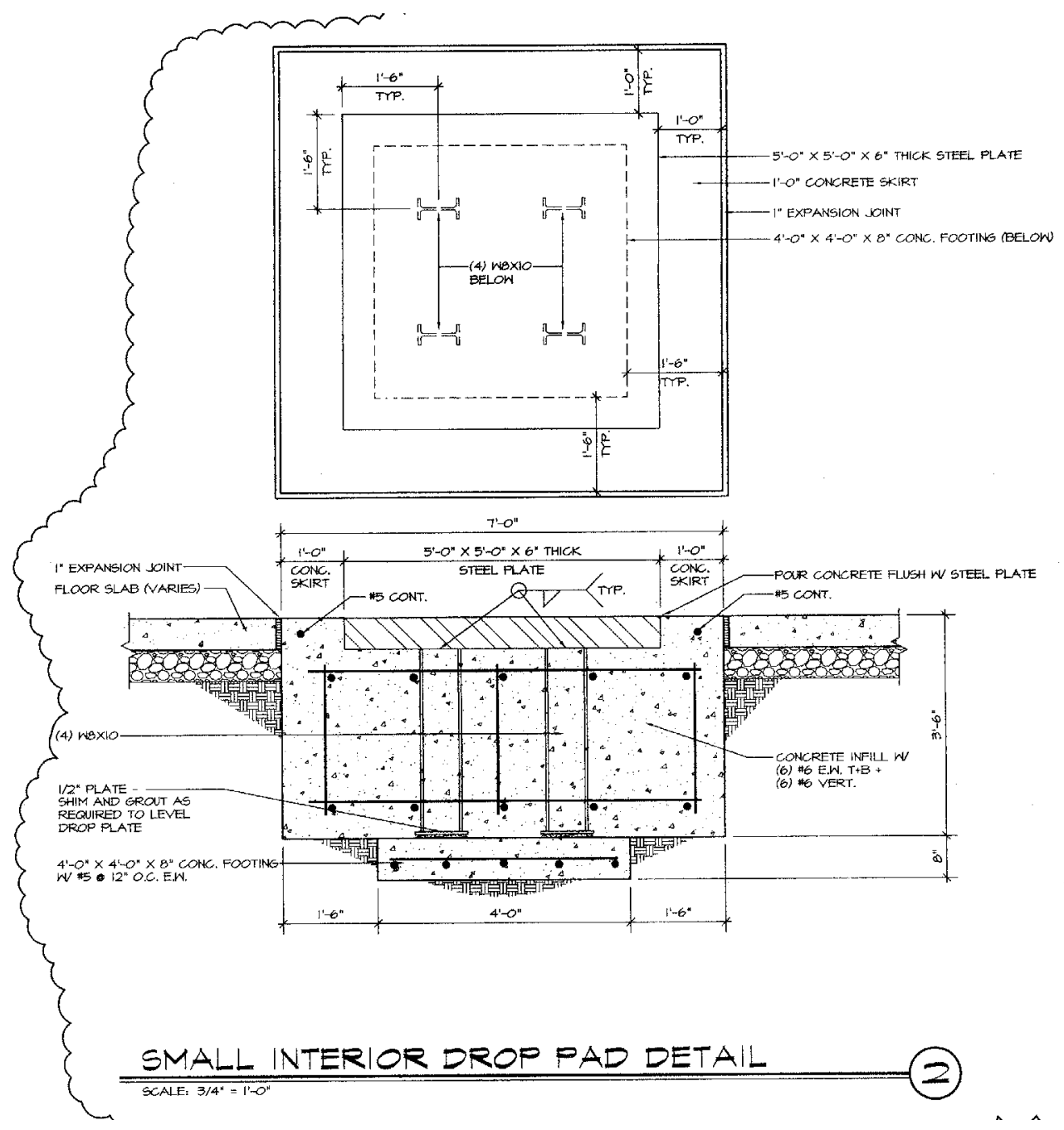

Fig. 8. Small interior drop pad design. 


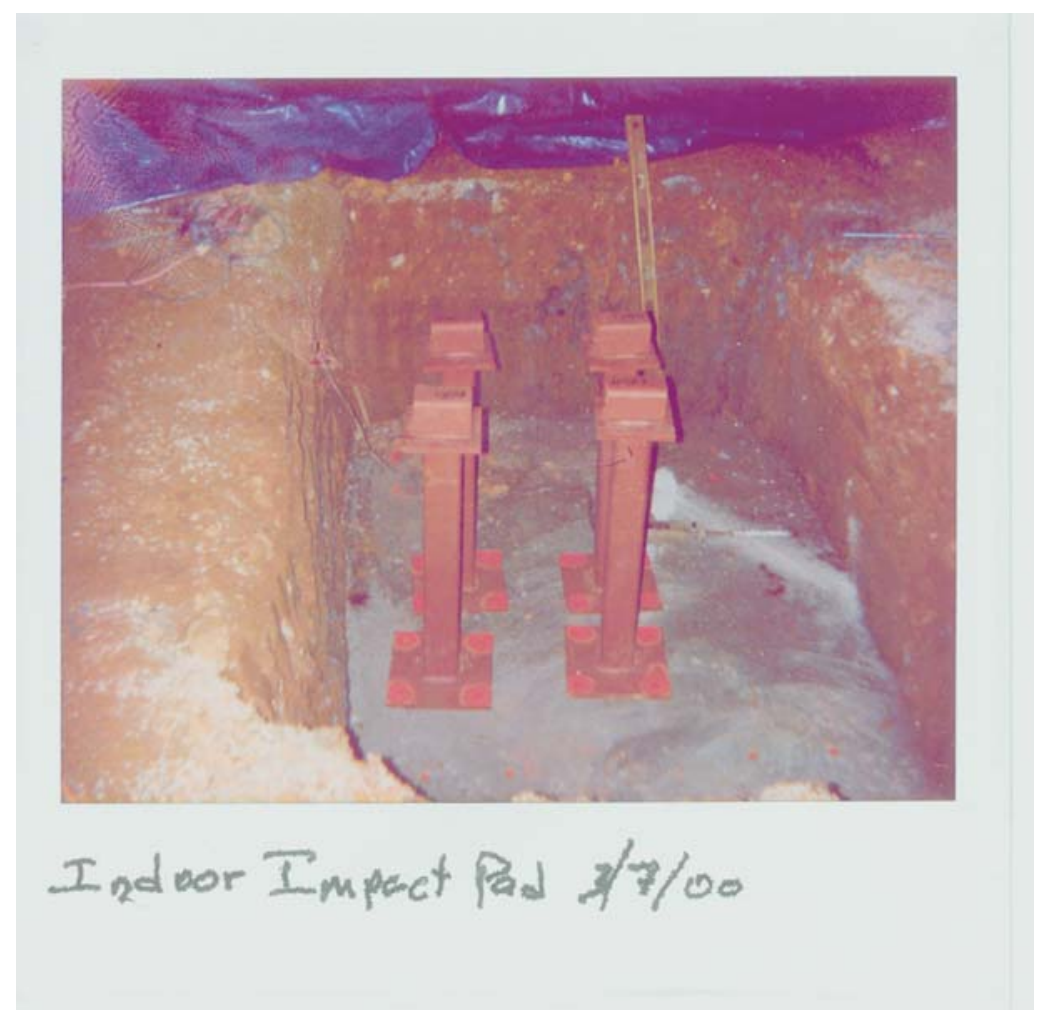

Fig. 9. Support posts for interior drop pad (end view).

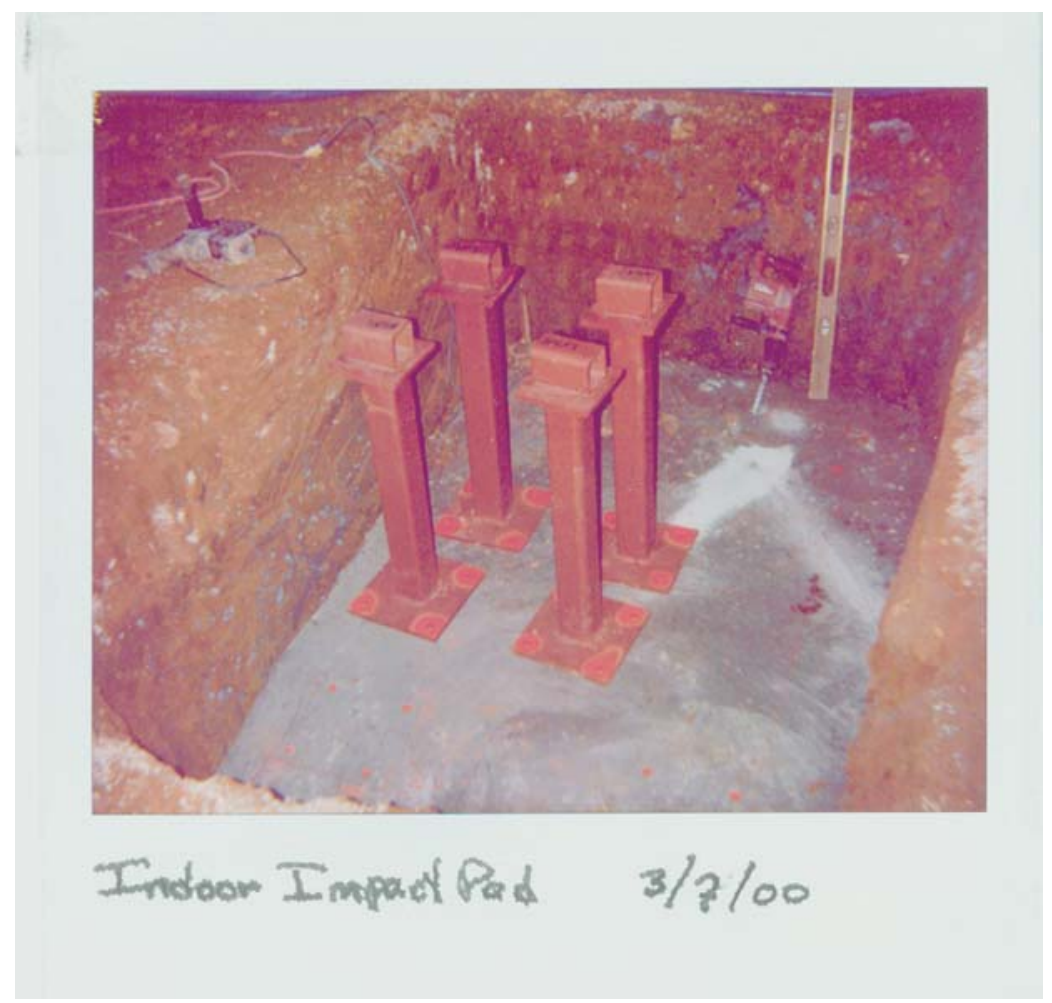

Fig. 10. Support posts for interior drop pad (corner view). 


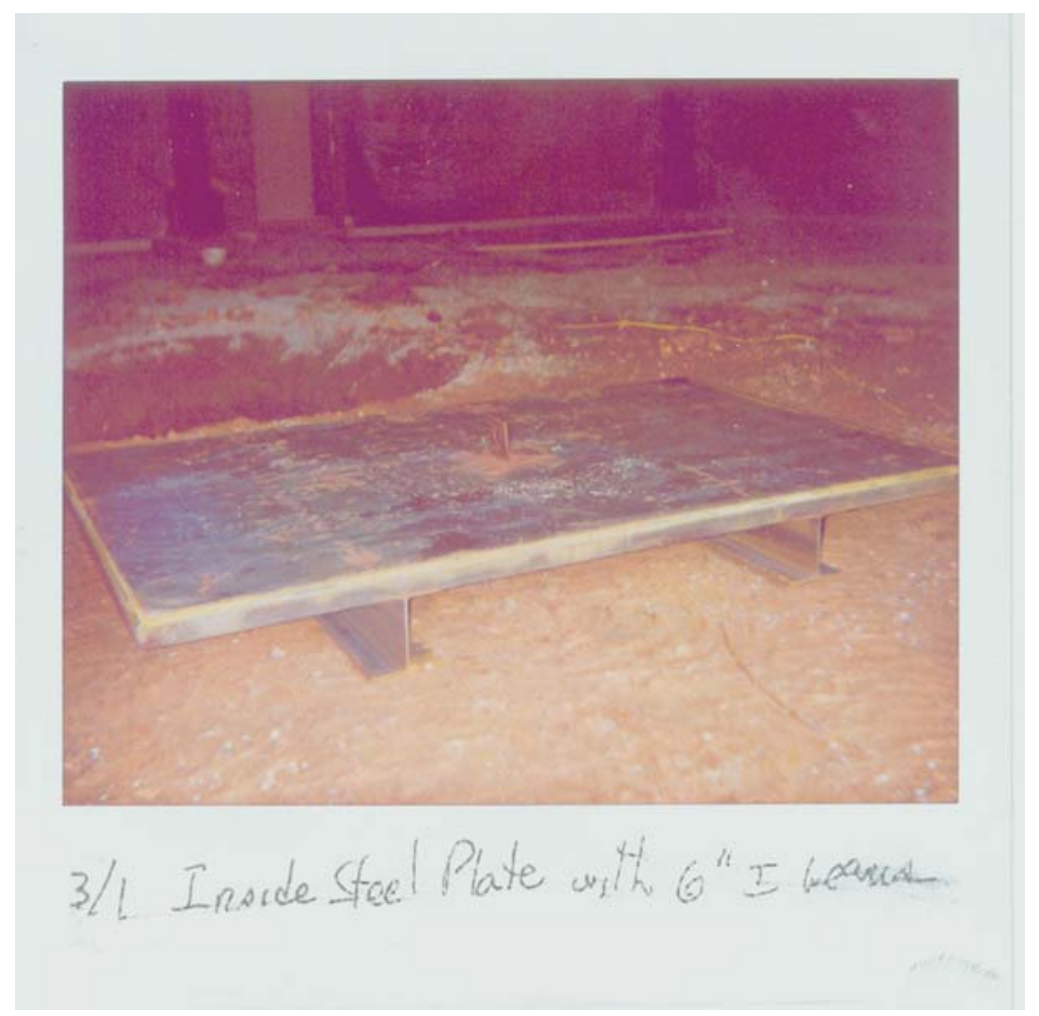

Fig. 11. Interior drop pad steel plate with 6" I-beams.

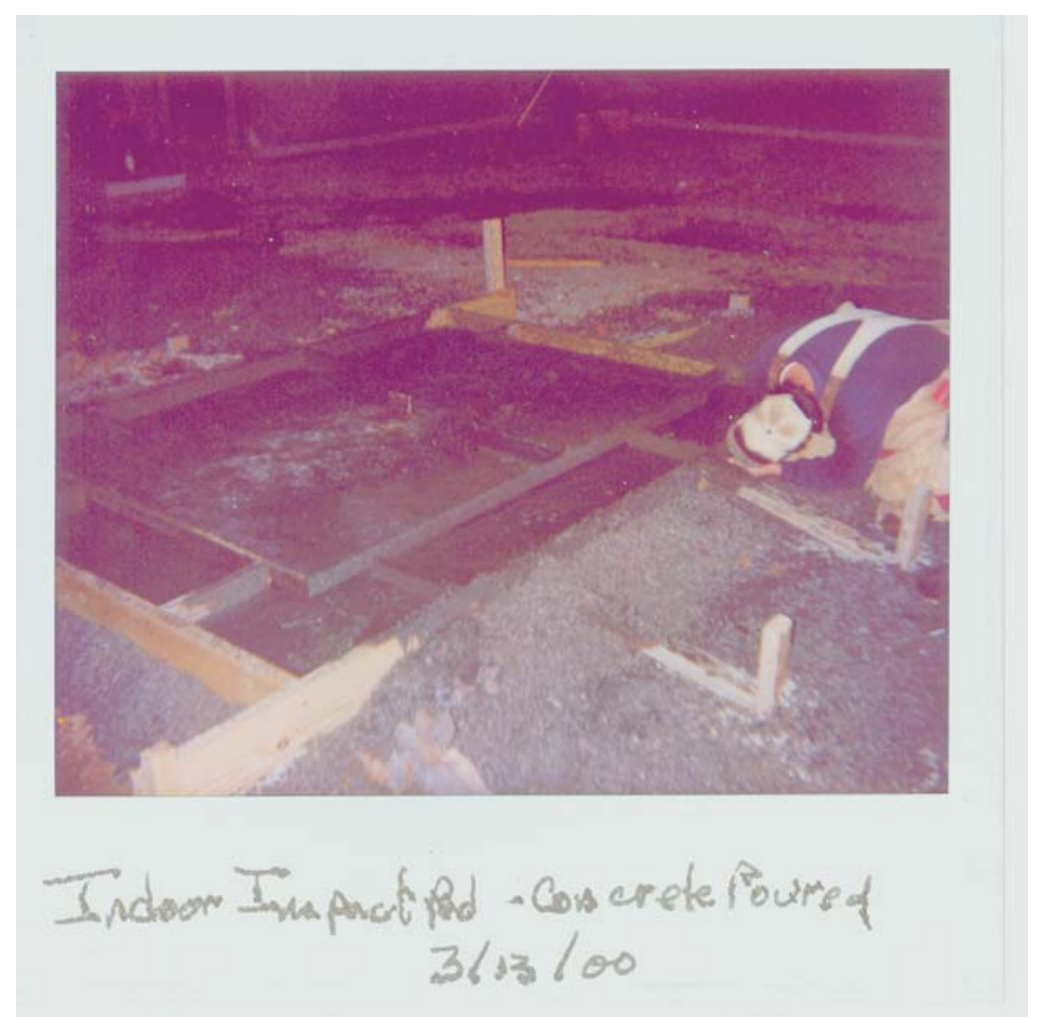

Fig. 12. Interior drop pad during final concrete pour. 
This page intentionally left blank. 


\subsection{CERTIFICATION OF IMPACT TARGETS AS "ESSENTIALLY UNYIELDING"}

Based on the IAEA Advisory Material described in the previous section (Refs. 6-8), the purpose of using an "essentially unyielding" target is to cause damage to a package that would be equivalent to or greater than that anticipated for impacts onto actual (real world) surfaces that might occur during transport. One example of an "unyielding" target is described as a 4-cm thick steel plate floated onto a concrete block mounted on firm soil or bedrock. It is important to note that mounting the target to bedrock is not required. Instead, the intent of the regulation is to ensure that an increase in the resistance of the target (to displacement or deformation) upon impact of a specimen "would not significantly increase the damage to the specimen." As a general "rule of thumb," the combined mass of the steel and concrete should be at least 10 times that of the specimen (for all NRC/IAEA Type B and special form tests) and 100 times that of the specimen (for all IAEA Type C tests). Further, the steel plate should have protruding fixed steel structures on its lower surface to ensure tight contact with the concrete.

Based on the design and construction details described in the previous section, the NTRC impact (target) pads have been constructed to fulfill the IAEA Advisory Material that forms the basis for both the IAEA and U.S. regulations.

\subsection{EVALUATION OF THE TOTAL TARGET MASS OF NTRC IMPACT PADS FOR TYPE B TESTS}

Based on the "as-built" dimensions of the impact pads (see Table 1), the total mass of the concrete and steel can now be estimated. For conservatism, the mass of the rebar and I-beams (or steel channel) that are embedded in the concrete (and serve to reinforced the structure) have been neglected. The density of steel (specifically ASTM A-36 steel plate) is assumed to be $490.09 \mathrm{lb} / \mathrm{ft}^{3}$ (calculated from Bethlehem Lukens Plate web page listing of masses and dimensions of A-36 plate steel items for sale). The density of concrete is assumed to be $144 \mathrm{lb} / \mathrm{ft}^{3}$ (Ref. 9, p. 6-8 for masonry concrete).

For the large (exterior) impact pad:

$$
\begin{array}{lll}
\text { Volume of steel plate: } & 242 \mathrm{in} \times 100.5 \mathrm{in} \mathrm{x} \text { in } / 1728 \mathrm{ft}^{3} / \mathrm{in}^{3} & =56.3 \mathrm{ft}^{3} \\
\text { Volume of concrete: } & \left(300 \mathrm{in} \times 159 \mathrm{in} \times 66 \mathrm{in} / 1728 \mathrm{ft}^{3} / \mathrm{in}^{3}\right)-56.3 \mathrm{ft}^{3}=1765.6 \mathrm{ft}^{3} \\
\text { Total mass: } & 56.3 \mathrm{ft}^{3} \times 490.09 \mathrm{lb} / \mathrm{ft}^{3}+1765.6 \mathrm{ft}^{3} \times 144 \mathrm{lb} / \mathrm{ft}^{3}=281,838 \mathrm{lb} .
\end{array}
$$

Based on the factor of 10 rule of thumb, the large (exterior) impact pad has a capacity of $281,838 \mathrm{lb}$ divided by 10 , or $28,184 \mathrm{lb}$ (i.e., 14 tons, or $12,784 \mathrm{~kg}$ ). Figure 13 shows the large exterior impact pad in use in September 2002.

For the small (interior) impact pad:

$$
\begin{array}{lll}
\text { Volume of steel plate: } & 75.5 \mathrm{in} \times 48.25 \mathrm{in} \times 2 \mathrm{in} / 1728 \mathrm{ft}^{3} / \mathrm{in}^{3} & =4.216 \mathrm{ft}^{3} \\
\text { Volume of concrete: } & \left(99.5 \mathrm{in} \times 72.5 \mathrm{in} \times 50 \mathrm{in} / 1728 \mathrm{ft}^{3} / \mathrm{in}^{3}\right)-4.216 \mathrm{ft}^{3}=204.51 \mathrm{ft}^{3} \\
\text { Total mass: } & 4.216 \mathrm{ft}^{3} \times 490.09 \mathrm{lb} / \mathrm{ft}^{3}+204.51 \mathrm{ft}^{3} \times 144 \mathrm{lb} / \mathrm{ft}^{3} & =31,516 \mathrm{lb} .
\end{array}
$$




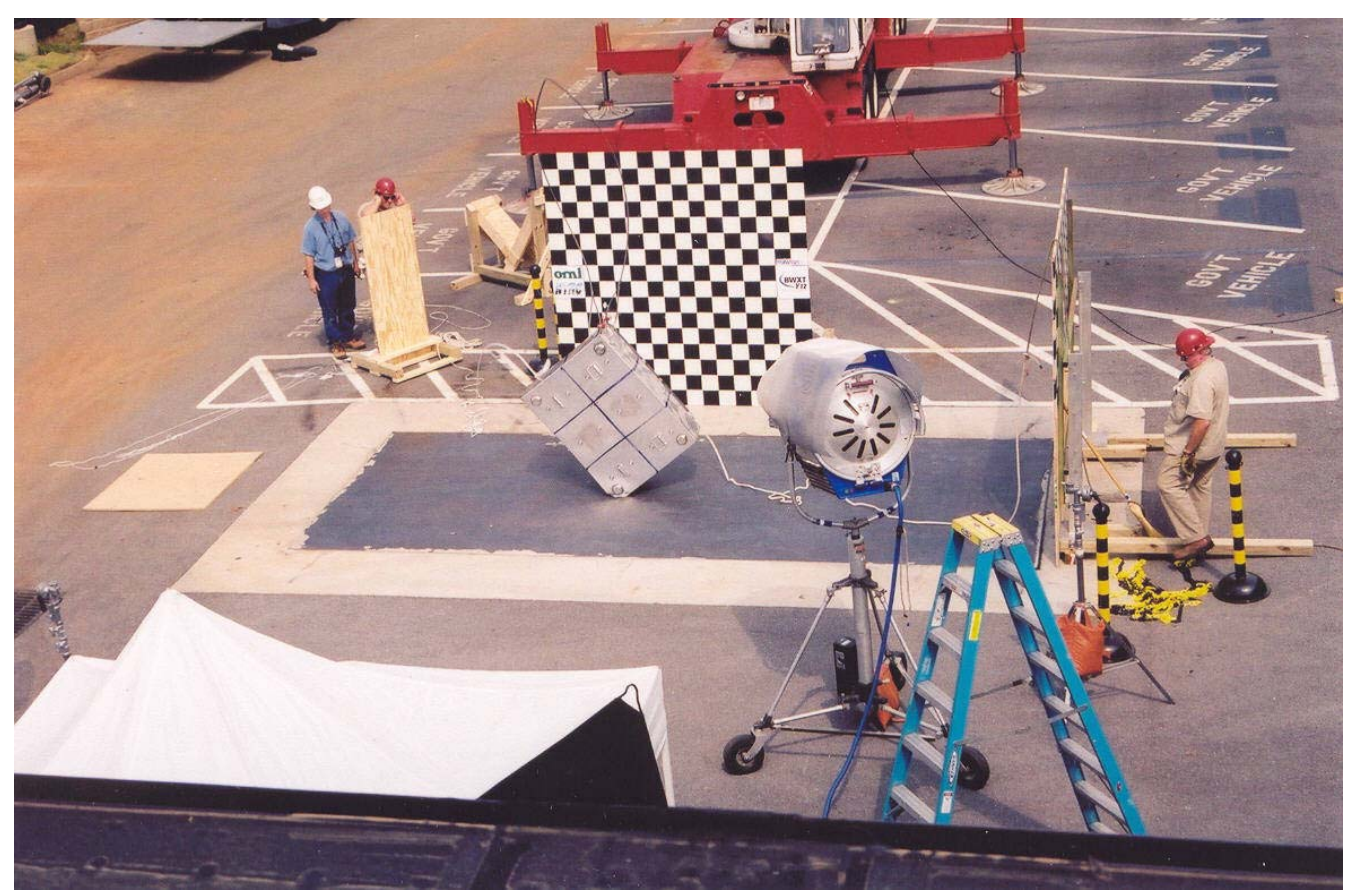

Fig. 13. Large exterior impact pad at the NTRC Packaging Research Facility.

Based on the factor of 10 rule of thumb, the small (interior) impact pad has a capacity of $31,516 \mathrm{lb}$ divided by 10 , or $3,152 \mathrm{lb}$ (or roughly 1.5 tons or $1,430 \mathrm{~kg}$ ). Figure 14 shows the small interior impact pad in use in December 2002.

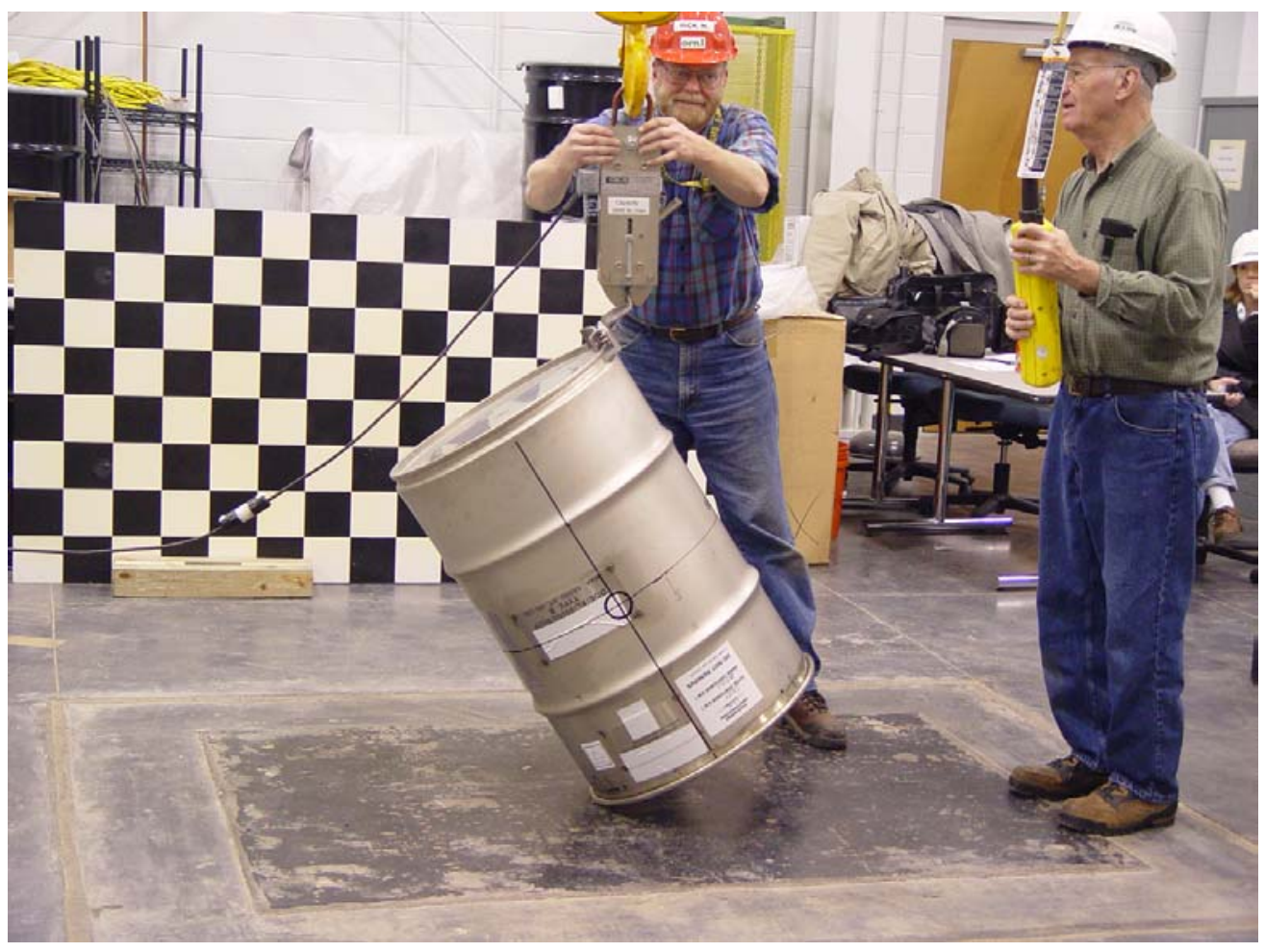

Fig. 14. Small interior impact pad at the NTRC Packaging Research Facility. 


\subsection{SUMMARY AND CONCLUSIONS}

Based on the design and analysis of the new NTRC impact (target) pads, as supported by the IAEA regulatory advisory material, it can be concluded that the impact (target) pads at the National Transportation Research Center each meet the regulatory definition of a "flat, essentially unyielding, horizontal surface" for use during package testing as prescribed in the NRC's regulations governing the packaging and transportation of radioactive material (10 CFR Part 71).

Based on the factor of 10 "rule of thumb" described in the IAEA advisory material, the general limiting capacity for packages (test specimens) has been defined as follows:

$\begin{array}{lll}\text { Large (exterior) impact pad: } & \text { Goal } & \begin{array}{l}\text { As-built capacity } \\ 28,184 \mathrm{lb}(12,784 \mathrm{~kg})\end{array} \\ \text { Small (interior) impact pad: } & 20,000 \mathrm{lb} & \\ & 3,000 \mathrm{lb} & 3,150 \mathrm{lb}(1,430 \mathrm{~kg})\end{array}$


This page intentionally left blank. 


\subsection{REFERENCES}

1. Genung, R. K., Jolley, R. L., and Mrochek, J.E., A Brief History of the Chemical Technology Division, ORNL/M-2733, Oak Ridge National Laboratory, Oak Ridge, Tennessee, May 1993.

2. Muckenthaler, F. J., The Tower Shielding Facility - Its Glorious Past, ORNL/TM-12339, Oak Ridge National Laboratory, Oak Ridge, Tennessee, May 7, 1997.

3. U.S. Code of Federal Regulations, "Packaging and Transportation of Radioactive Material," Part 71, Chapter I, Title 10, "Energy."

4. International Atomic Energy Agency, "Regulations for the Safe Transport of Radioactive Material," 1985 Edition (As Amended 1990), IAEA Safety Standards, Safety Series No. 6, Vienna, 1990.

5. International Atomic Energy Agency, "Regulations for the Safe Transport of Radioactive Material," 1996 Edition (Revised), IAEA Safety Standards Series, No. TS-R-1 (ST-1, Revised), Vienna, 2000.

6. International Atomic Energy Agency, "Explanatory Material for the IAEA Regulations for the Safe Transport of Radioactive Material (1985 Edition)," Second Edition (As Amended 1990), IAEA Safety Guides, Safety Series No. 7, Vienna, 1990.

7. International Atomic Energy Agency, "Advisory Material for the IAEA Regulations for the Safe Transport of Radioactive Material (1985 Edition)," Third Edition (As Amended 1990), IAEA Safety Guides, Safety Series No. 37, Vienna, 1990.

8. International Atomic Energy Agency, "Advisory Material for the IAEA Regulations for the Safe Transport of Radioactive Materials," IAEA Safety Standards Series, No. TS-G-1.1 (ST-2), Vienna, 2002.

9. Marks'Standard Handbook for Mechanical Engineers, ed. Baumeister, T., Avallone, E. A., and Baumeister III, T., Eighth Edition, McGraw-Hill, Inc., New York, 1978. 
This page intentionally left blank. 


\section{INTERNAL DISTRIBUTION}
1. W. S. Aaron
2. K. K. Anderson
3. S. T. Baker
4. T. W. Burgess
5. R. M. Canon
6. A. G. Croff
7. D. W. DePaoli
8. L. S. Dickerson
9. L. D. Duncan
10. E. C. Fox
11. L. D. Gasaway
12. R. G. Gilliland
13. S. R. Greene
14. M. B. Hawk
15. J. N. Herndon
16. D. J. Hill
17. D. T. Ingersoll
18. P. E. Johnson
19. B. L. Kirk
20. B. E. Lewis
21-31. S. B. Ludwig
32. S. C. Marschman
33. G. T. Mays
34. G. E. Michaels
35. R. D. Michelhaugh
36. S. D. Moses
37. C. V. Parks
38. B. D. Patton
39. R. R. Rawl
40. W. J. Reich
41. A. W. Riedy
42. J. E. Rushton
43. L. J. Satkowiak
44. L. B. Shappert
45. J. H. Shelton
46. P. T. Singley
47. D. J. Spellman
48. P. S. Tarlton
49. T. D. Welch
50. R. M. Wham
51. J. D. White
52. D. L. Williams
53. G. L. Yoder
54. R. E. Ziegler
55-59. NTRC Packaging Research Facility
60. ORNL OTIC-RC, CRL, OSTI

\section{EXTERNAL DISTRIBUTION}

61. C. M. Amonett, Y-12 National Security Complex, BWXT Y-12, LLC, P.O. Box 2009, Oak Ridge, TN 37831

62. M. A. Barela, U.S. Department of Energy, Albuquerque Operations Office, P.O. Box 5400, Albuquerque, NM 87185-5400

63. S. Bellamy, Westinghouse Savannah River Company, Road 1, Bldg 773-53A, Aiken, SC 29808

64-66. G. V. Binns, U.S. Department of Energy, Albuquerque Operations Office, P.O. Box 5400, Albuquerque, NM 87185-5400

67. P. Blanton, Westinghouse Savannah River Company, Road 1, Bldg 773-53A, Aiken, SC 29808

68. R. W. Boyle, DHM-23, U.S. Department of Transportation, Research and Special Programs Administration, Office of Hazardous Materials Safety, $4007^{\text {th }}$ Street, S.W., Washington, DC 20590

69. J. P. Bozik, NA-262, U.S. Department of Energy, 1000 Independence Avenue, S.W., Washington, DC 20585-1290

70. E. W. Brach, MS 13 D13, U.S. Nuclear Regulatory Commission, One White Flint North, 11555 Rockville Pike, Rockville, MD 20852-2738 
71. G. L. Clark, P.E., Packaging Technology, Inc., 1102 Broadway Plaza, Suite 300, Tacoma, WA 98402

72. Mr. R. H. Clark, Duke Cogema Stone \& Webster, FC12A, P.O. Box 31847, Charlotte, NC 28231-1847

73. M. J. Conroy, EM-24, U.S. Department of Energy, 1000 Independence Avenue, S.W., Washington, DC 20585-2040

74. J. R. Cook, MS 13 D13, U.S. Nuclear Regulatory Commission, One White Flint North, 11555 Rockville Pike, Rockville, MD 20852-2738

75. M. R. Feldman, Y-12 National Security Complex, BWXT Y-12, LLC, P.O. Box 2009, Building 9113, Oak Ridge, TN 37831

76. P. C. Ferrell, Duratek Federal Services of Hanford, Inc., P.O. Box 700, MSIN H1-11, Richland, WA 99352-0700

77. C. Gaynor, Honeywell FM\&T/Kansas City, 2000 East 95th Street, P.O. Box 419159, Kansas City, MO 64141-6159

78. J. K. Hancock, EM-24, U.S. Department of Energy, 1000 Independence Avenue, S.W., Washington, DC 20585-2040

79. M. Hassler, Y-12 National Security Complex, BWXT Y-12, LLC, P.O. Box 2009, Building 9113, Oak Ridge, TN 37831

80. M. R. Jones, U.S. Department of Energy, Albuquerque Operations Office, P.O. Box 5400, Albuquerque, NM 87185-5400

81. M. J. Klimas, U.S. Department of Energy, Chicago Operations Office, 9800 South Cass Avenue, Argonne, IL 60439

82. J. G. Lanthrum, U.S. Department of Energy, Albuquerque Operations Office, P.O. Box 5400, Albuquerque, NM 87185-5400

83. P. B. Lester, U.S. Department of Energy, Oak Ridge Operations, P.O. Box 2001, Oak Ridge, TN 37831

84. R. J. Lewis, MS 13 D13, U.S. Nuclear Regulatory Commission, One White Flint North, 11555 Rockville Pike, Rockville, MD 20852-2738

85. S. E. McClanahan, Y-12 National Security Complex, BWXT Y-12, LLC, P.O. Box 2009, Building 9113, Oak Ridge, TN 37831

86. J. Nichols, Packaging Technology, Inc., 1102 Broadway Plaza, Suite 300, Tacoma, WA 98402

87. P. Noss, Packaging Technology, Inc., 1102 Broadway Plaza, Suite 300, Tacoma, WA 98402

88. S. M. Nunley, U.S. Department of Energy, Albuquerque Operations Office, P.O. Box 5400, Albuquerque, NM 87185-5400

89. E. Opperman, Westinghouse Savannah River Company, Road 1, Bldg 730-B, Aiken, SC 29808

90. N. L. Osgood, MS 13 D13, U.S. Nuclear Regulatory Commission, One White Flint North, 11555 Rockville Pike, Rockville, MD 20852-2738

91. R. B. Pope, International Atomic Energy Agency, P.O. Box 100, Wagramer Strasse 5, A-1400 Vienna, Austria

92. S. A. Porter, Portemus Engineering, Inc., 925 North Alder Street, Tacoma, WA 98406-6317

93. P. T. Rhoads, NA-261, U.S. Department of Energy, 1000 Independence Avenue, S.W., Washington, DC 20585-1290

94. D. F. Stancell, U.S. Department of Energy, Oak Ridge Operations, P.O. Box 2001, Oak Ridge, TN 37831

95. S. A. Thompson, U.S. Department of Energy, Albuquerque Operations Office, P.O. Box 5400, Albuquerque, NM 87185-5400 
96. D. R. Tousley, NA-261, U.S. Department of Energy, 1000 Independence Avenue, S.W., Washington, DC 20585-1290

97. M. E. Wangler, International Atomic Energy Agency, P.O. Box 100, Wagramer Strasse 5, A-1400 Vienna, Austria

98. D. M. Willaford, U.S. Department of Energy, Oak Ridge Operations, P.O. Box 2001, Oak Ridge, TN 37831

99. J. R. Williams, RW-46, U.S. Department of Energy, 1000 Independence Avenue, S.W., Washington, DC 20585-1290

100. F. Yapunich, Packaging Technology, Inc., 1102 Broadway Plaza, Suite 300, Tacoma, WA 98402

101. D. K. Zabranski, RW-44, U.S. Department of Energy, 1000 Independence Avenue, S.W., Washington, DC 20585-1290 